\title{
Citation Analysis of Higher Education Texts in Selected Databases: A Comparison between 2002-2006 and 2007-2011
}

\author{
Chin-Hsiu Tai, Che-Wei Lee, and Yender Lee
}

\begin{abstract}
In this article, we aimed to investigate the dynamics of higher education texts from 2002 to 2011 by identifying the most frequently cited references, the highest cited authors, and the correlations among the co-citations. Citation and Co-Citation analyses were used to examine 1,941 cited journal articles from 41,001 publications published in SCI and SSCI databases. We juxtaposed the status of citations between two periods of 2002-2006 and 2007-2011. Results showed research trends changed significantly. Some generative reflections, methodological limitations, future research recommendations were discussed as well.
\end{abstract}

Index Terms-Higher education, citation analysis, co-citation analysis, citation-enhanced databases.

\section{INTRODUCTION}

Albeit the first Western universities, which were established in Paris and Bologna, have existed since the twelfth century [1]-[6], higher education as an academic discipline in the research that employs the citation indexing methodology [7] to graphically and quantitatively document the emerging and competing education texts, the most influential scholars, and the correlations among the author co-citations remains scant [8]. This methodological chasm, in one degree or another, hinders the development of the research territory of higher education [8].

Hence, how to swiftly, efficiently, and accurately locate the classic (must-read, best-quality, and wide-cited) texts related to higher education has become an indispensable capability, demand, and challenge for potential academic novices, or even seasoned/senior faculty members at times, especially facing the era within the rapid evolution of the Internet, the dramatic proliferation of new technologies, various types of software and programs, and the explosion of knowledge that complicate the process of doing a literature search in a way [9], [10]. Many scholars even identify this competence of the highest-speeding data mining or knowledge generation as one of the reputation indicators that contributes to academic productivity and publication quality in the making of the world-class university rankings [11]-[13].

In the first twenty-first century, higher education research paradigm has emerged various paradigm shifts that heavily

Manuscript received January 12, 2013; revised March 13, 2013.

C.-H. Tai and Y. Lee are with the Graduate School of Business and Operations Management, Chang Jung Christian University, Tainan 71101, Taiwan (R.O.C.) (e-mail: a8646165@yahoo.com.tw, mcgill_lee@yahoo.com).

C. $-\bar{W}$. Lee is with the Institute for International Studies in Education, University of Pittsburgh, PA 15206, USA (e-mail: leejeiwei@gmail.com) emphasize on marketization [14], globalization [15], McDonaldization [16], and New Managerialism [17]-[19], the alignment/integration of digital technologies, effective finance management, and academic capitalism [20]-[26]. Yet this variation in patterns of research falls short of a documentary evidence sufficient to visualize this paradigm transformation.

The purpose of this study was thus, in terms of a quantitative viewpoint, to help identify the linkage among different publications and to confirm their statuses and positions in their contributions to the development of higher education research field. We aim to help academic novices and potential contributors quickly grasp the unabridged picture of higher education field from 2002 to 2011 based on the condition of the citations in selected databases. Furthermore, we intend to form a timely comprehensively-established knowledge structure as a cognitive basis and threshold for future studies in this field. Those who are interested in higher education research can benefit from our pilot study and thereby devoted more time to engaging in the epistemological innovation and methodological breakthrough, rather than identifying the prominent scholars along with their celebrated works.

Four research questions focus on (a) which references (journals and books) were cited the most, (b) whose works were the most frequently cited, and (c) who were highly nominated?

\section{METHOD}

\section{A. Research Design}

We employed Garfield's [7] citation indexing as our methodology, combined with the citation [27] and author co-citation analyses [28] richly used in the bibliometrics [29], [30] and cybermetrics [30], as well as scientometrics [31], [32]. To compare the dynamics of the cited authors, references, co-cited authors in 2002-2006 with that in 2007-2011, we divided a ten-year timeline into two periods respectively since contemporary higher education research studies for the past decades has generated research paradigm shift since 2002 [20]-[26]. The objective of this study is to provide the researchers of higher education with a complete understanding by ranking publications according to the total number of the citations. The ranking we designed was based on publications in Thomson Reuters' Web of Science database in the period of 2002-2011.

\section{B. Data Source}

Our data analyzed in this study derived from the Social 
Citation Index (SCI) and Social Science Citation Index (SSCI). Because of the characteristics of peer review, strict filtering mechanism, the most accepted and comprehensive databases, more than 9,000 world's leading scholarly journals have been published in this generally acknowledged and selected database. We therefore selected the publications related to higher education as our targeted data analyzed. Only publications in the sciences and the social sciences are included. Publications in the arts and humanities are excluded because in these domains the bibliometric indicators of the Leiden Ranking do not have sufficient accuracy. Furthermore, only publications of the Web of Science document types article, letter, and review are considered in the Leiden Ranking. The data cited in this study included authors, journal articles, publication outlets, cited references, and publication dates. It was worth note that we seemingly focused our search on the journal articles, yet we found that in fact the results included the online journals (e.g., The Chronicle of Higher Education), e-/books, e-/volumes, and international organizations' reports (e.g., Work Bank) automatically.

\section{Data Collection Procedure}

Searches for peer-reviewed articles were conducted in SCI and SSCI databases. We restrained our search from 2002 to 2011 because a prior review from these perspectives was published in 2002. We identified the sources of the publications in higher education research from the SCI and SSCI databases. Then we designed a data mining means to retrieve the authors, topics, and journals closely associated with higher education research. The key word for search was higher education. 1,941 search results were found out from 41,001 publications, including journal articles, books, volumes, and online journals.

\section{Data Analysis}

We utilized the Microsoft Excel 2010 sheets to screen, sort, sub-total, sum, and rank the collected data by the citation frequency. Then we restrained our amount of refined data to the top 30 results, and identified the key nodes in the invisible network of knowledge through tabulations of the citation status, including the most frequently cited references, the highly nominated authors followed by the highest cited works. Finally, we used co-citation analysis to tabulate the author factor loadings.

\section{RESULTS}

Two primary results demonstrated the dynamics of reference citation in the field higher education between 2002-2006 and 2007-2011. The following tabulates the knowledge distribution process.

\section{A. Which References Were Cited the Most?}

TABLE I lists the ranking of the 17 most frequently cited journals during the periods of 2002-2006 and 2007-2011. All number of the citation frequency averages over 110 times. The rankings 1 to 3,6 , and 12 remain the same journals within the two periods, including Research in Higher Education, Journal of Higher Education, Higher Education, Journal of College Student Development, and British Journal of Educational Psychology in sequence.
TABLE I: RANKING COMPARISON OF THE 17 MOST FREQUENTLY CiTED REFERENCES, 2002-2006 AND 2007-2011

\begin{tabular}{|c|c|c|}
\hline Rank & $\begin{array}{c}\text { Journal/Book Title, 2002-2006 } \\
\text { (No. of Citations) }\end{array}$ & $\begin{array}{c}\text { Journal/Book Title, 2007-2011 } \\
\text { (No. of Citations) }\end{array}$ \\
\hline 1* & $\begin{array}{l}\text { Research in Higher Education } \\
(979)\end{array}$ & $\begin{array}{l}\text { Research in Higher Education } \\
(1,617)\end{array}$ \\
\hline $2 *$ & $\begin{array}{l}\text { Journal of Higher Education } \\
\text { (956) }\end{array}$ & $\begin{array}{l}\text { Journal of Higher Education } \\
(1,409)\end{array}$ \\
\hline $3 *$ & Higher Education (663) & Higher Education $(1,174)$ \\
\hline 4 & $\begin{array}{l}\text { Review of Higher Education } \\
(450)\end{array}$ & $\begin{array}{l}\text { Studies in Higher Education } \\
\text { (743) }\end{array}$ \\
\hline 5 & $\begin{array}{l}\text { Studies in Higher Education } \\
(378)\end{array}$ & $\begin{array}{l}\text { Review of Higher Education } \\
\text { (648) }\end{array}$ \\
\hline $6^{*}$ & $\begin{array}{l}\text { Journal of College Student } \\
\text { Development (340) }\end{array}$ & $\begin{array}{l}\text { Journal of College Student } \\
\text { Development (448) }\end{array}$ \\
\hline 7 & $\begin{array}{l}\text { Higher Education: Handbook } \\
\text { of Theory (Book Series) } \\
\text { (283) }\end{array}$ & Sociology of Education (331) \\
\hline 8 & Change (249) & $\begin{array}{l}\text { Higher Education Research } \\
\text { and Development (321) }\end{array}$ \\
\hline 9 & $\begin{array}{l}\text { The Chronicle of Higher } \\
\text { Education (on-line journal) } \\
\text { (211) }\end{array}$ & $\begin{array}{l}\text { Higher Education Handbook of } \\
\text { Theory (Book Series) (265) }\end{array}$ \\
\hline 10 & Sociology of Education (192) & $\begin{array}{l}\text { Journal of Educational } \\
\text { Psychology (234) }\end{array}$ \\
\hline 11 & $\begin{array}{l}\text { Journal of Educational } \\
\text { Psychology(187) }\end{array}$ & $\begin{array}{l}\text { Review of Educational } \\
\text { Research (224) }\end{array}$ \\
\hline $12 *$ & $\begin{array}{l}\text { British Journal of Educational } \\
\text { Psychology (178) }\end{array}$ & $\begin{array}{l}\text { British Journal of Educational } \\
\text { Psychology (223) }\end{array}$ \\
\hline 13 & $\begin{array}{l}\text { Review of Educational } \\
\text { Research (162) }\end{array}$ & $\begin{array}{l}\text { American Sociological Review } \\
\text { (205) }\end{array}$ \\
\hline 14 & $\begin{array}{l}\text { Economics of Education } \\
\text { Review (160) }\end{array}$ & $\begin{array}{l}\text { How College Affects Students: } \\
\text { A Third Decade of Research, } \\
\text { Vol. } 2 \text { (192) }\end{array}$ \\
\hline 15 & $\begin{array}{l}\text { Higher Education Research } \\
\text { and Development (151) }\end{array}$ & $\begin{array}{l}\text { American Journal of Sociology } \\
\text { (181) }\end{array}$ \\
\hline 16 & $\begin{array}{l}\text { American Sociological } \\
\text { Review (140) }\end{array}$ & $\begin{array}{l}\text { Economics of Education } \\
\text { Review (180) }\end{array}$ \\
\hline 17 & $\begin{array}{l}\text { Administrative Science } \\
\text { Quarterly (116) }\end{array}$ & Change (164) \\
\hline
\end{tabular}

\section{B. Whose Works Were the Most Frequently Cited?}

Table II indicates the ten most frequently cited publications from 2002 to 2006 along with the specific name(s) of the author(s) followed by the publication years. Pascarella and Terenzini's [33] work stands the first place according to the total number of citations, which is 88 times. Astin's [34] work ranked the second place was cited 63 times. Biggs' [35] and Tinto's [36] works share the sixth place with the identical citation frequency of 39, whereas Becher's [37] and Gibbons, et al.'s [38] works are tied for the eighth place with the equal citation frequency of 36 . The rest of those ranged between 49 and 35 cited times include Slaughter and Leslie's [39], Boyer's [40], Tinto's [41], and Clark's [42] works.

Similarly, Table III shows the top 10 highest cited works between 2006 and 2011. Tinto's [41] work was promoted to the first place, where has replaced the position of Pascarella and Terenzini's [33] work which was ranked the second place, followed by Astin's [34] piece. In this last five years Biggs' [35], Becher's [37], and Clark's [42] were excluded from the top 10 highly cited list, while Becher and Trowler [43] packed into it as the eighth ranking. Interestingly, Pascarella and Terenzini [44] simultaneously appeared twice as the rankings number four and six. It was likely because this work was cited by a whole book or book section. 
TABLE II: LIST OF THE 10 MOST FREQUENTLY REFERENCES, 2002-2006

\begin{tabular}{clc}
\hline \hline Rank & Abbreviated Bibliographic Entries & No. of Citations \\
\hline 1 & E.T.Pascarella\&P.T.Terenzini 1991 & 88 \\
2 & A.W.Astin 1993 & 63 \\
3 & S.Slaughter\&L.L.Leslie 1997 & 49 \\
4 & E.L.Boyer 1990 & 47 \\
5 & V.Tinto 1993 & 42 \\
6 & J.B.Biggs 1999 & 39 \\
6 & V.Tinto 1975 & 39 \\
8 & T.Becher 1989 & 36 \\
8 & M.Gibbons,etal. 1994 & 36 \\
10 & B.R.Clark 1983 & 35 \\
\hline \hline
\end{tabular}

Note. See the complete bibliography in appendix.

TABLE III: LIST OF THE 10 MOST FREQUENTLY CITED REFERENCES, 2007-2011

\begin{tabular}{clc}
\hline \hline Rank & Abbreviated Bibliographic Entries & No. of Citations \\
\hline 1 & V.Tinto 1993 & 85 \\
2 & E.T.Pascarella\&P.T.Terenzini 1991 & 69 \\
3 & A.W.Astin 1993 & 65 \\
4 & E.T.Pascarella\&P.T.Terenzini 2005 & 57 \\
5 & S.Slaughter\&L.L.Leslie 1997 & 53 \\
6 & E.T.Pascarella\&P.T.Terenzini 2005 & 52 \\
7 & V.Tinto 1975 & 51 \\
8 & T.Becher\&P.R.Trowler 2001 & 46 \\
9 & E.L.Boyer 1990 & 44 \\
10 & M.Gibbons,etal. 1994 & 41 \\
\hline \hline
\end{tabular}

Note. See the complete bibliography in appendix.

\section{Who Were Highly Nominated?}

TABLE IV presents the ten most frequently cited authors from 2002 to 2006. Ernest T. Pascarella was the highest cited author during this period, whereas Alexander W. Astin stood the second place. After Vincent Tinto who was ranked the third position, the other authors were cited lower than 100 times.

TABLE IV: List OF THE 10 Most FREQUENTLy Cited Authors, 2002-2006

\begin{tabular}{clc}
\hline \hline Rank & Author & No. of Citations \\
\hline 1 & Pascarella, Ernest T. & 151 \\
2 & Astin, Alexander W. & 137 \\
3 & Tinto, Vincent & 120 \\
4 & Kuh, George D. & 91 \\
5 & Clark, Burton. R. & 90 \\
6 & Becher, Tony & 77 \\
7 & Marton, Ference Istvan & 73 \\
8 & Slaughter, Sandra A. & 62 \\
9 & Biggs, John B. & 59 \\
10 & Boyer, Ernest Leroy & 54 \\
\hline \hline
\end{tabular}

TABLE V: List of THE 10 Most FREQUENTLy Cited Authors, 2007-2011

\begin{tabular}{clc}
\hline \hline Rank & Author & No. of Citations \\
\hline 1 & Pascarella, Ernest T. & 232 \\
2 & Tinto, Vincent & 183 \\
3 & Kuh, George D. & 129 \\
4 & Astin, Alexander W. & 119 \\
5 & Slaughter, Sandra A. & 97 \\
6 & Becher, Tony & 89 \\
7 & Hurtado, Sylvia & 86 \\
8 & Clark, Burton. R. & 78 \\
8 & Marton, Ference Istvan & 78 \\
10 & Biggs, John B. & 76 \\
\hline \hline
\end{tabular}

TABLE V shows the top ten highly cited authors between 2007 and 2011. Ernest T. Pascarella stayed the first place, while Vincent Tinto was promoted to be the second place, where replaced Alexander W. Astin who has transformed to the fourth position. George D. Kuh was advanced to the third position in this phase. The rest of authors' citations averaged below 100 times. Surprisingly, Sylvia Hurtado entered this top 10 highly cited roll as the seventh status, whereas Ernest Leroy Boyer has been eliminated from this competition over a short span of five years.

\section{DiscusSION AND CONCLUSION}

Four critical reflections on the outcomes of our examined quantitative data include (a) the cautions of treating the highly cited journals (b) the warnings about the use of the most frequently cited works, and (c) the implications for the development of higher education from the highly nominated authors.

First, we unveiled that the journals in higher education field has a high-speed replacement ratio between 2002-2006 and 2007-2011. Amid 17 journals, merely 5 journals maintain their academic authority for the latter 5 years. Many researchers in this area seemingly tend to publish their best works in the top 3 journals that contribute to advance their established worldwide reputation much higher, such as Research in Higher Education, Journal of Higher Education, and Higher Education. Yet this ranking roster solely based on the citation frequency fails to justify that the quality of the relatively-less cited journals is poor. Without having deliberate understanding of the characteristics of various journals, the prospective contributors are likely to miss the fittest journals for their specific subfields, or to blindly contribute to the journals with the highest impact factor devised by Garfield [7] because of a conformity mentality. Some new contributors more often feel frustrated because of the wrong journal choices that make publication more unlikely.

Second, our ranking design helped recognize the most frequently cited works that provide new academics with a good sense to locate the standard of the high quality publications. The value of these leading works that dominate the higher education research paradigm not just create several landmarks in the evolution of higher education scholarship that position the authors' historical significance, but also unfold the life cycle of the popularity of certain research topics. Nonetheless, we should be continually aware of that the citation frequency of a piece is insufficient to overgeneralize that is the sole cause of becoming a classic production, although it can be one of at least the bottom lines. The sophistication of knowledge in a work is the essence of excreting it to the world's foremost authority. Barely relying on the quantitatively-cumulative citation frequency to judge the impact of the works of those recently emerging scholars is unfair.

Third, the nine most frequently cited authors maintaining in the roll of top 10 highest cited authors from 2002 to 2011 still consolidate their position. Though this study identified that facilitate academic novices to quickly know some influential scholars in higher education scholarship, a potential obstacle to the development of higher education research lies in the scarce interaction with other outstanding authors with differing backgrounds, including nations, languages, ethnicity/race, etc. 
Finally, by means of the citation analysis some biases still inevitably emerged against new scholars who place more emphasis on the publication quality, as opposed to the quantity, of the documents produced by a given scholar than a ranking of authors based on the frequencies with which a paper-based ranking (as in Table II and III) and a particular author has been cited (as in Tables IV and V). Moreover, we can see the key research themes in a field to indicate the popularity of certain research topics and preference according to Table II and III. We argue this likely causes publication privatization without other various contributors' engagement. The result further indicate high citations have influence on what can be termed field-defining titles and they lay down the ground work for the understanding of higher education research as a distinct phenomenon. Tables II and III showed a pattern from the first five years to the second five years. First of all, the most influential publications in the last five years dominated their positions for the past five years on higher education research. Finally, the past decade have extensive research commitment to higher education. This methodological consideration for macro mapping in higher education field has the potential to lead to future research directions, as several aspects of this research have not been conducted previously. The mapping of the intellectual structure of higher education studies has somehow created its own literature that has gained the reputation as a legitimate academic field, with specific journals related to higher education research gaining the status qualified for an independent research field.

\section{REFERENCES}

[1] B. Wildavsky, The Great Brain Race: How Global Universities Are Reshaping the World, Princeton, NJ: Princeton University Press, 2010, ch. 1, pp. 14-41.

[2] A. Hall, Managing People, Berkshire, U.K.: Open University Press, 2003, ch. 1, pp. 1-7.

[3] R. O. Berdahl, P. G. Altbach, and P. J. Gumport, "Introduction: The contexts of American higher education," in American Higher Education in the Twenty-First Century: Social, Political, and Economic Challenges, 3rd ed., P. G. Altbach, P. J. Gumport, and R. O. Berdahl, Eds. Baltimore, MD: The Johns Hopkins University Press, 2011, pp. 1-11

[4] P. G. Altbach, "Patterns of higher education development," in American Higher Education in the Twenty-First Century: Social, Political, and Economic Challenges, 3rd ed., P. G. Altbach, P. J. Gumport, and R. O. Berdahl, Eds. Baltimore, MD: The Johns Hopkins University Press, 2011, ch. 1, pp. 15-36.

[5] R. L. Geiger, "The ten generations of American higher education," in American Higher Education in the Twenty-First Century: Social, Political, and Economic Challenges, 3rd ed., P. G. Altbach, P. J. Gumport, and R. O. Berdahl, Eds. Baltimore, MD: The Johns Hopkins University Press, 2011, ch. 2, pp. 37-68.

[6] R. O. Berdahl, "Academic freedom: Past, present, and future," in American Higher Education in the Twenty-First Century: Social, Political, and Economic Challenges, 3rd ed., P. G. Altbach, P. J. Gumport, and R. O. Berdahl, Eds. Baltimore, MD: The Johns Hopkins University Press, 2011, ch. 4, pp. 88-110.

[7] E. Garfield, Citation Indexing - Its Theory and Application in Science, Technology, and Humanities, New York: John Wiley \& Sons, 1979, ch 1-ch. 10, pp. 1-252.

[8] R. L. Geiger, Knowledge and Money: Research Universities and the Paradox of the Marketplace, Stanford, CA: Standard University Press, 2004, ch. 4, pp. 132-179.

[9] W. F. Massy, "Productivity issues in higher education," in Resource Allocation in Higher Education, W. F. Massy, Ed. Ann Arbor, MI: The University of Michigan Press, 1996, ch. 3, pp. 49-86.

[10] C. Hart, Doing a Literature Search: A Comprehensive Guide for the Social Sciences, Thousand Oaks, CA: Sage Publications, 2001, pp. $1-194$.
[11] G. Federkeil, "Reputation indicators in rankings of higher education institutions," in University Rankings, Diversity, and the New Landscape of Higher Education, B. M. Kehm and B. Stensaker, Eds. Rotterdam, The Netherlands: Sense Publishers, 2009, pp. 19-33.

[12] P. G. Altbach and J. Balán, World Class Worldwide: Transforming Research Universities in Asia and Latin America, Baltimore, MD: The Johns Hopkins University Press, 2007, pp. 1-312

[13] J. Salmi, The Challenge of Establishing World-Class Universities, Washington, DC: The World Bank, 2009, pp. 1-115.

[14] S. M. Natale and C. Doran, "Marketization of education: An ethical dilemma," Journal of Business Ethics, vol. 105, no. 2, pp. 187-196, Jan. 2012.

[15] R. A. Morrow and C. A. Torres, "The state, globalization, and educational policy," Globalization and Education: Critical Perspectives, N. C. Burbules and C. A. Torres, Eds, New York: Routledge, 2000, pp. 27-56.

[16] D. Hayes and R. Wynyard, Ed, The McDonalidization of Higher Education, Westport, CT: Bergin \& Garvey, 2002, pp. 1-210.

[17] D. Braun, "New managerialism and the governance of universities in a comparative perspective," in Towards a New Model of Governance for Universities? A Comparative View, D. Braun and F.-X. Merrien, EDs, Philadelphia, PA: Jessica Kinsley Publishers, 1999, pp. 239-261.

[18] R. Deem, "New managerialims in UK universities: Manager-academic accounts of change," in Globalization and Reform in Higher Education, H. Eggins, Ed, Berkshire, U.K.: Society for Research into Higher Education \& Open University Press, 2003, pp. 1-246.

[19] R. Deem, S. Hillyard, and M. Reed, Knowledge, Higher Education, and the New Managerialism: The Changing Management of UK Universities, Oxford: Oxford University, 2007, pp. 1-245.

[20] D. B. Johnstone, "Financial higher education: Who should pay?" in American Higher Education in the Twenty-First Century: Social, Political, and Economic Challenges, 3rd ed., P. G. Altbach, P. J. Gumport, and R. O. Berdahl, Eds. Baltimore, MD: The Johns Hopkins University Press, 2011, ch. 12, pp. 315-340.

[21] J. Willinsky, G. Fischman, and A. S. Metcalfe, "The digital technologies of learning and research," in American Higher Education in the Twenty-First Century: Social, Political, and Economic Challenges, 3rd ed., P. G. Altbach, P. J. Gumport, and R. O. Berdahl, Eds. Baltimore, MD: The Johns Hopkins University Press, 2011, ch. 13, pp. 341-364.

[22] P. J. Gumport, "Graduate education and research: Interdependence and strain," in American Higher Education in the Twenty-First Century: Social, Political, and Economic Challenges, 3rd ed., P. G. Altbach, P. J. Gumport, and R. O. Berdahl, Eds. Baltimore, MD: The Johns Hopkins University Press, 2011, ch. 14, pp. 365-408.

[23] M. N. Bastedo, "Curriculum in higher education: The organizational dynamics of academic reform," in American Higher Education in the Twenty-First Century: Social, Political, and Economic Challenges, 3rd ed., P. G. Altbach, P. J. Gumport, and R. O. Berdahl, Eds. Baltimore, MD: The Johns Hopkins University Press, 2011, ch. 15, pp. 409-432.

[24] S. Slaughter and G. Rhoades, "Markets in higher education: Trends in academic capitalism," in American Higher Education in the Twenty-First Century: Social, Political, and Economic Challenges, 3rd ed., P. G. Altbach, P. J. Gumport, and R. O. Berdahl, Ed. Baltimore, MD: The Johns Hopkins University Press, 2011, ch. 16, pp. 433-464.

[25] D. G. Smith, "The diversity imperative: Moving to the next generation," in American Higher Education in the Twenty-First Century: Social, Political, and Economic Challenges, 3rd ed., P. G. Altbach, P. J. Gumport, and R. O. Berdahl, Ed. Baltimore, MD: The Johns Hopkins University Press, 2011, ch. 17, pp. 433-464.

[26] J. E. Graoccia and J. E. Miller, Eds, On Becoming a Productive University: Strategies for Reducing Costs and Increasing Quality in Higher Education, Bolton, MA: Anker, pp. 1-331.

[27] H. F. Moed, Citation Analysis in Research Evaluation, Dordrecht, The Netherlands: Springer, 2005, pp. 1-335.

[28] S. Eom, Author Cocitation Analysis: Quantitative Methods for Mapping the Intellectual Structure of an Academic Discipline, Hershey, PA: Information Science Reference, 2009, pp. 1-.342.

[29] S. E. Beck and K. Manuel, Practical Research Methods for Librarians and Information Professionals, New York: Neal-Schuman Publishers, 2008, ch. 7, pp. 165-194.

[30] N. D. Bellis, Bibliometrics and Citation Analysis: From the Science Citation Index to Cybermetrics, Lanham, MD: Scarecrow Press, 2009, pp. 1-394.

[31] S. Harnad, "Open access scientometrics and the UK research assessment exercise," Scientometrics, vol. 79, no. 1, pp. 147-156, April 2009.

[32] S. Harnad, "Validating research performance metrics against peer rankings," Ethics in Science and Environmental Politics, vol. 8, pp. 103-107. 
[33] E. T. Pascarella and P. T. Terenzini, How College Affects Students: Findings and Insights from Twenty Years of Research, San Francisco, CA: Jossey-Bass, 1991.

[34] A. W. Astin, "What matters in college?" Liberal Education, vol. 79, no. 4, pp. 4-15, Fall 1993.

[35] J. B. Biggs, Teaching for Quality Learning at University: What the Student Does, Buckingham: Society for Research into Higher Education and Open University Press, 1999, pp. 1-250.

[36] V. Tinto, "Dropout from higher education: A theoretical synthesis of recent research," Review of Educational Research, vol. 45, no. 1, pp. 89-125, Jan. 1975.

[37] T. Becher, Academic Tribes and Territories: Intellectual Enquiry and the Cultures of Disciplines, Philadelphia, PA: The Society for Research into Higher Education and Open University Press, 1989, pp. 1-200.

[38] M. Gibbons, C. Limoges, H. Nowotny, S. Schwartzman, P. Scott, and M. Trow, The New Production of Knowledge: The Dynamics of Science and Research in Contemporary Societies, London: Sage, 1994, pp. 1-179.

[39] S. Slaughter and L. L. Leslie, Academic Capitalism: Politics, Policies, and the Entrepreneurial University, Baltimore, MD: Johns Hopkins University Press, 1997, pp. 1-276.

[40] E. L. Boyer, Scholarship Reconsidered: Priorities of the Professoriate, Lawrenceville, NJ: Princeton University Press, 1990, pp. 1-147.

[41] V. Tinto, Leaving College: Rethinking the Causes and Cures of Student Attrition, 2nd ed. Chicago: The University of Chicago Press, 1993, pp. $1-296$.

[42] B. R. Clark, The Higher Education System: Academic Organization in Cross-National Perspective. Berkeley and Los Angeles: University of California Press, 1983, pp. 1-315.

[43] T. Becher and P. R. Trowler, Academic Tribes and Territories: Intellectual Enquiry and the Culture of Disciplines, 2nd ed. Buckingham: The Society for Research into Higher Education and Open University Press, 2001, pp. 1-2000.

[44] E. T. Pascarella and P. T. Terenzini, How College Affects Students: A Third Decade of Research, vol. 2. San Francisco, CA: Jossey-Bass, 2005 , pp. $1-.827$

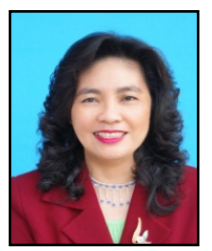

Chin-Hsiu Tai is library director and mathematics teacher of Lai-Yi High School in Pingtung, and a Doctoral student in the Graduate School of Business and Operations Management at the Chang Jung Christian University in Taiwan. She received a MA degree in Mathematics from the National Kaohsiung Normal University in 2002 and the degree of Master of Business Administration (MBA) from the National University of Kaohsiung in 2011. Prior to joining the Lai-Yi high school, Tai has served in a number of leadership during education positions as a primary school teacher and teaching director in Taiwan.

Her research interests include educational leadership, ethical leadership and decision making in education, education management, strategic marketing for educational institutions, and human resources. Tai is also a member of several professional memberships and associations, including the Academy of Management (AOM), Administrative Sciences Association of Canada (ASAC), Australian and New Zealand Academy of Management (ANZAM), and Decision Science Institute (DSI). She also has written and published various topics related to mathematics, education management, human resources, and technology management in many academic conferences.

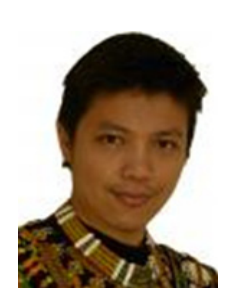

Che-Wei Lee is program coordinator at the University of Pittsburgh Institute for International Studies in Education (IISE) in the United States, which is located in the School of Education. Lee is also a doctoral student in the Social and Comparative Analysis in Education Program. Prior to pursuing his graduate studies in National Chung Cheng University (CCU) in Chiayi, Lee earned his Bachelor of Education (BEd) from National Pingtung University of Education. Lee received his Master of Education in Graduate Institute of Education at CCU in Chiayi, Taiwan in 2008 with an emphasis in indigenous education issues of culture, language, and identity in relation to secondary education. He served as a research assistant for several projects on Taiwan Aboriginal education and cultural identity issues. His research interests include indigenous higher education, indigenous methodologies, comparative education, international organization and development education, anthropology of education, and cultural anthropology. Recent publications include a chapter with Dr. Kuan-Ting Tang "Reconstructing Subject and the Tenuous Praxis of Liberating Education: A Critical Ethnography of an Aboriginal Community-based School" in an edited book The Compilation of Indigenous Peoples 2009 (2009) published by the Council of Indigenous Peoples, Executive Yuan, and one forthcoming chapter with Dr. W. James Jacob and Jing Liu, "Policy Debates and Indigenous Education: The Trialectic of Language, Culture and Identity" in a forthcoming edited volume, entitled Indigenous Education: Language, Culture, and Identity (forthcoming) scheduled for publication by Springer in 2013. Prior to joining the University of Pittsburgh's IISE, Lee has served in a number of leadership during his studies and education position as a primary school teacher in Taiwan. Lee is also a member of several Professional Memberships and Associations, including Comparative and International Education Society (CIES), Chinese Comparative Education Society-Taipei (CCEST), Taiwan Higher Education Society (THES), Taiwan Association for Sociology of Education (TASE), and Association for Curriculum and Instruction, Taiwan, R.O.C. (ACI). He is currently working on IISE's Indigenous Education Project with Drs. W. James Jacob, Sheng-Yao Cheng, and Maureen Porter.

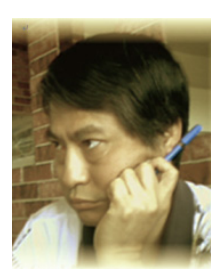

Yender Lee is professor of Graduate School of Business and Operations Management at the Chang Jung Christian University in Taiwan. Lee holds a PhD from McGill University in 2002. His research focuses on scientometrics and bibliometrics for the knowledge network; information science and knowledge management; strategic management for science, technology, and innovation venture capital; and international business management. He has written and published widely on these topics with colleagues in some leading journals such as the Business Ethnics: A European Review, Technological Forecasting and Social Change, Technovation, International Journal of Conflict Management, and co-edited books and book chapters. Since 2005 Lee has established an international and interdisciplinary association of learning by doing and has devoted the past decade of his academic and professional life to facilitating to promote an invisible network of knowledge for publishing collaboration. He is also an active member of the Academy of Management (AOM), Administrative Sciences Association of Canada (AASC), Australian and New Zealand Academy of Management (ANZAM) since the late 1990s and has been an active member at annual conferences, regional conferences, and in various leadership positions. 